\title{
DISCLAIMER
}

This report was prepared as an account of work sponsored by an agency of the United States Government. Neither the United States Government nor any agency thereof, nor any of their employees, makes any warranty, express or implied, or assumes any legal liability or responsibility for the accuracy, completeness, or usefulness of any information, apparatus, product, or process disclosed, or represents that its use would not infringe privately owned rights. Reference herein to any specific commercial product, process, or service by trade name, trademark, manufacturer, or otherwise does not necessarily constitute or imply its endorsement, recom. mendation, or favoring by the United States Government or any agency thereof. The views and opinions of authors expressed herein do not necessarily state or reflect those of the United States Government or any agency thereof.

$$
\text { PNL-SA- }-18808
$$

DE91 004810

\section{INFLUENCE OF COLD WORK AND PHOSPHORUS CONTENT ON NEUTRON-INDUCED SWELLING OF $\mathrm{Fe}-\mathrm{Cr}-\mathrm{NI}$ ALLOYS}

\author{
F. A. Garner
}

October 1990

Prepared for
inclusion in
Fusion Reactor Materials
Semiannual Progress
Report DOE/ER-0313/9

Work supported by the

U.S. Department of Energy

under Contract DE-ACO6-76RLO 1830

\section{Pacific Northwest Laboratory Richland, Washington 99352}

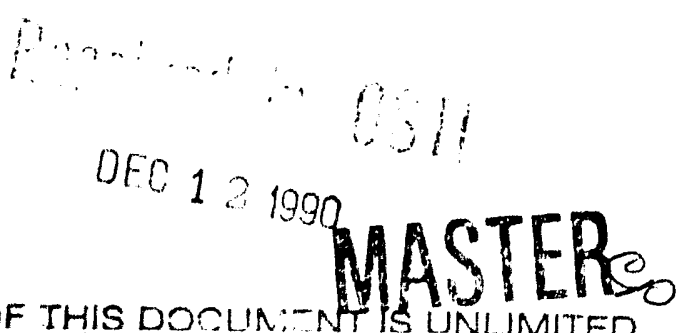

DISTFIEUTION OF THIS DOCLIR:-NTS UNI IMITFE 
INFLUENCE OF COLD WORK AND PHOSPHORUS CONTENT ON

NEUTRON-INDUCED SWELLING OF Fe-Cr-Ni ALLLOYS

F. A. Garner (Pacific Northwest Laboratory) (a)

\section{OBJECTIVE}

The overall objective of this effort was to determine the origin of the sensitivity of void swelling and mi zrostructural evolution in irradiated metals to environmental and material variables. A more specific objective was to assist in the interpretation of the results of the ${ }^{59} \mathrm{Ni}$ doping experiment designed to study the separate and synergistic effects of helium and other variables. Two of these variables are cold working and phosphorus content.

\section{SUMMARY}

Phosphorus additions can either increas a or decrease void sweiling of $\mathrm{Fe}-\mathrm{Cr}-\mathrm{Ni}$ alloys, depending on irradiation temperature, phosphorus level and cold work level. The role of cold work is not always to suppress swelling in $\mathrm{Fe}-\mathrm{Cr}-\mathrm{Ni}-\mathrm{P}$ alloys, however, particularly at relatively higher irradiation temperatures, where cold working often increases swelling substantially.

\section{INTRODUCTION}

Frequently one can generalize the action of a particular variable on a given physical process in terms of its most often observed behavior, which would indicate a single major role for that variable. For example, it is well established that the addition of either phosphorus or silicon generally suppresses the onset of void swelling in austenitic alloys. Recently, however, it has been shown that under some conditions the addition of relatively low levels of either solute can substantially increase swelling in simple $\mathrm{Fe}-\mathrm{Cr}-\mathrm{Ni}$ alloys, $(1,2)$ as shown in Figures 1 and 2 . This complex behavior is thought to indicate that two or more competing mechanisms

(a) Operated for the U.S. Department of Energy by Battelle Memorial Institute under Contract DE-ACO6-76RLO 1830. 


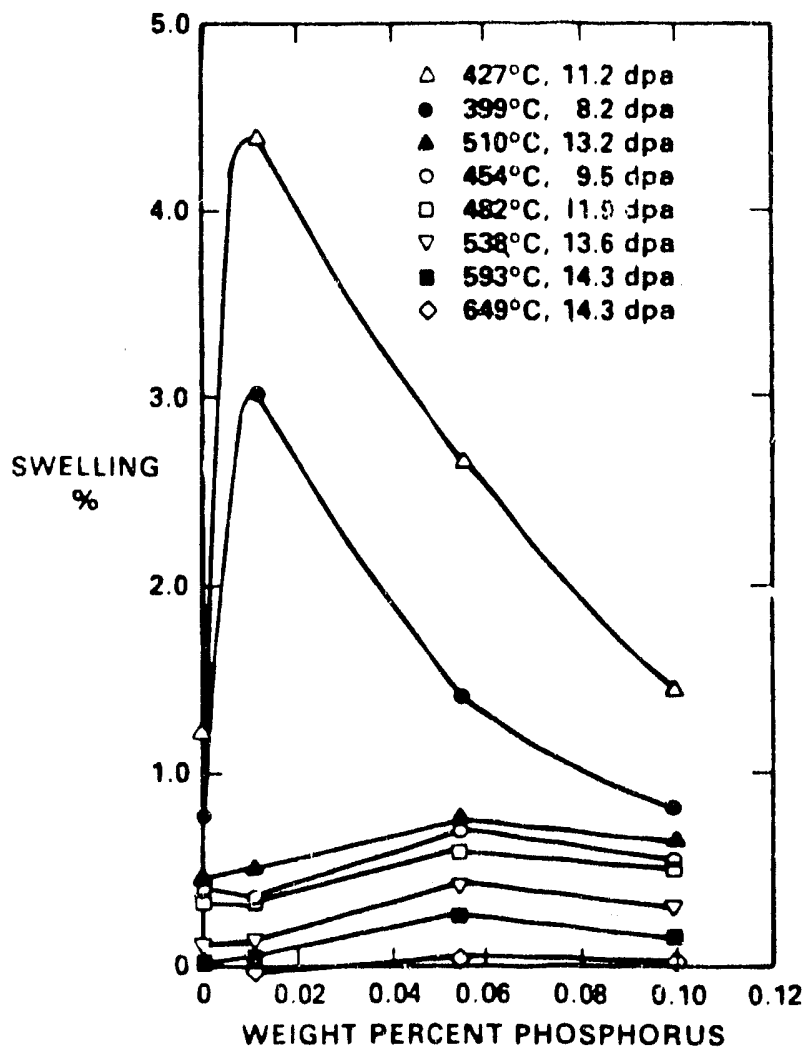

FIGURE 1. Influence of Phosphorus on Neutron-Induced Swelling in EBR-II (AA-IX experiment) of $\mathrm{Fe}-25 \mathrm{Ni}-15 \mathrm{Cr}$, at Various Combinations of Temperature and Fluence $(1)$

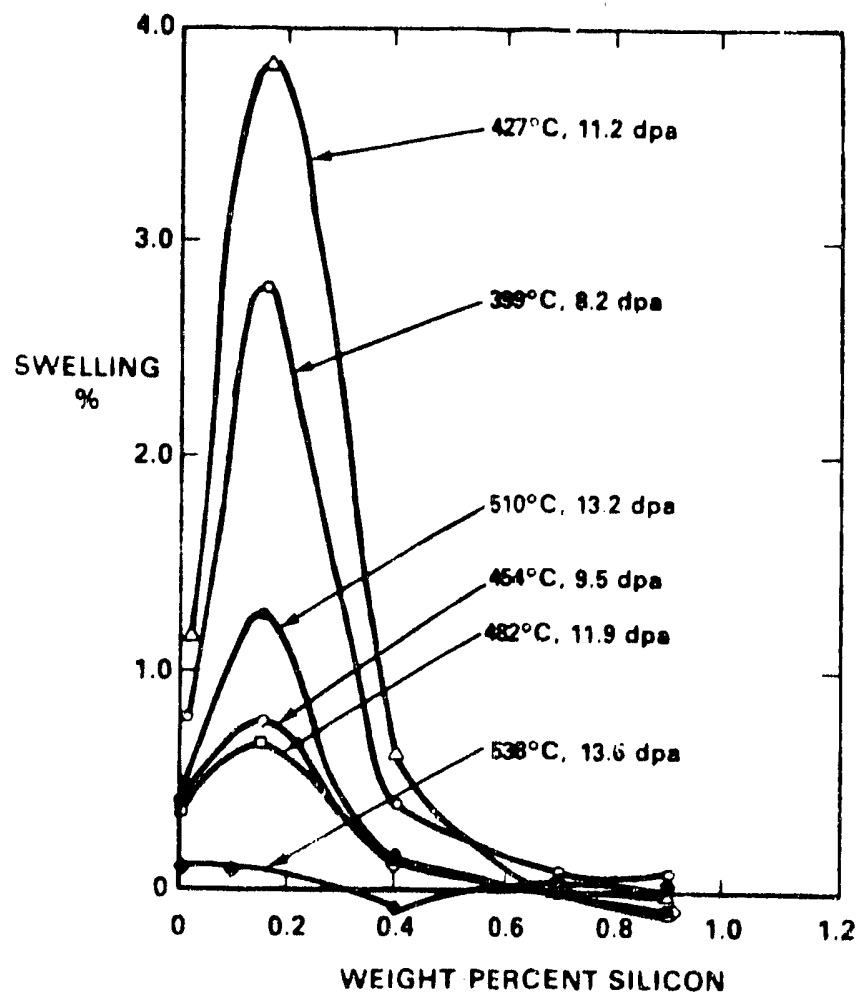

FIGURE 2. Influence of Silicon on Neutron-Induced Swelling in EBR-II (AA-IX experiment) of $\mathrm{Fe}-25 \mathrm{Ni}-15 \mathrm{Cr}$ at Various Combinations of Temperature and Fluence $(1)$ 
involwing these elements are operating to control swelling and that in some cases the competition is dominated by a secondary or tertiary mechanism.

As reviewed in reference 1 , phosphorus forms precipitates at relatively high temperatures and concentration levels and strongly interacts with both vacancies and interstitials at all temperatures. Phosphorus also acts to maintain dislocations induced by cold working, although this latter possibility has not been explored previously in simple austenitic alloys. A search was therefore initiated for previously irradiated specimens that would allow study of the interactive effects of phosphorus and cold work.

The most extensive set of such specimens was found in the ${ }^{59} \mathrm{Ni}$-doping helium effects experiments conducted in FFTF on $\mathrm{Fe}-15 \mathrm{Cr}-25 \mathrm{Ni}$ and $\mathrm{Fe}-15 \mathrm{Cr}-$ $25 \mathrm{Ni}-0.04 \mathrm{P}$ (wt\%). (3-5) Unfortunately, the major influence of phosphorus in increasing swelling lies in the range below $0.04 \%$ and at temperatures below $\sim 500^{\circ} \mathrm{C}$. In this temperature range of the ${ }^{59} \mathrm{Ni}$ experiment, density data have been measured only for the first discharge at $5.2 \mathrm{dpa}$, which is below the threshold of significant swelling. Higher exposure data are now being accumulated.

In another experiment, however, four nominally identical $\mathrm{Fe}-15 \mathrm{Cr}-25 \mathrm{Ni}$ alloys, varying primarily in phosphorus content, were irradiated as TEM disks in the FFTF fast reactor to doses in excess of $30 \mathrm{dpa}$ at 420,520 and $600^{\circ} \mathrm{C}$ $\left( \pm 5^{\circ} \mathrm{C}\right)$ in both the annealed and $30 \%$ cold worked conditions. The compositions of these alloys in Table 1, are identical to those that were irradiated in EBR-II and shown in Figure 1. Immersion density measurements were performed on two identical specimens at each condition.

TABLE 1. Phosphorus-Modified Alloys Irradiated in FFTF-MOTA to $>30 \mathrm{dpa}$

$\begin{array}{ll}\text { E33 } & \mathrm{Fe}-25.8 \mathrm{Ni}-14.8 \mathrm{Cr}(\leq 0.005 \mathrm{P}) \\ \text { E103 } & \mathrm{Fe}-24.1 \mathrm{Ni}-14.7 \mathrm{Cr}-0.013 \mathrm{P} \\ \mathrm{E} 104 & \mathrm{Fe}-25.0 \mathrm{Ni}-15.2 \mathrm{Cr}-0.055 \mathrm{P} \\ \mathrm{E} 105 & \mathrm{Fe}-24.7 \mathrm{Ni}-15.3 \mathrm{Cr}-0.10 \mathrm{P}\end{array}$

One of the alloys in this experiment, E104 (Fe-15Cr-25Ni-0.055P), was also irradiated as TEM disks in EBR-II in the AA-XIV experiment to $14 \mathrm{dpa}$ at 425,500 and $600^{\circ} \mathrm{C}$. In this experiment the alloys were irradiated in each of 
the annealed $\left(975^{\circ} \mathrm{C} / 10 \mathrm{~m} / \mathrm{WQ}\right), 30 \%$ cold worked, and the cold worked and aged $\left(650^{\circ} \mathrm{C} / 10 \mathrm{~m} / \mathrm{WQ}\right)$ conditions. Immersion density measurements were performed on one specimen each of every combination of starting condition and irradiation temperature.

\section{RESULTS}

Swelling values for the FFTF irradiation were calculated from density change data and are shown in Figure 3. Each data point, with one exception, represents the average of two separate but identical disks, whose densities agree within the $\pm 0.16 \%$ established as the convergence criterion for this measurement technique. The exception was the cold worked alloy E33 (lowest phosphorus level) at $420^{\circ} \mathrm{C}$, where some variability was observed.

At $420^{\circ} \mathrm{C}$ and $36.6 \mathrm{dpa}$ the swelling behavior observed in FFTF in both the annealed and cold worked specimens mirrors that seen in the same alloys when irradiated in the annealed condition in EBR-II at 399 and $427^{\circ} \mathrm{C}$, illustrating once again the various outcomes of the competition of those mechanisms

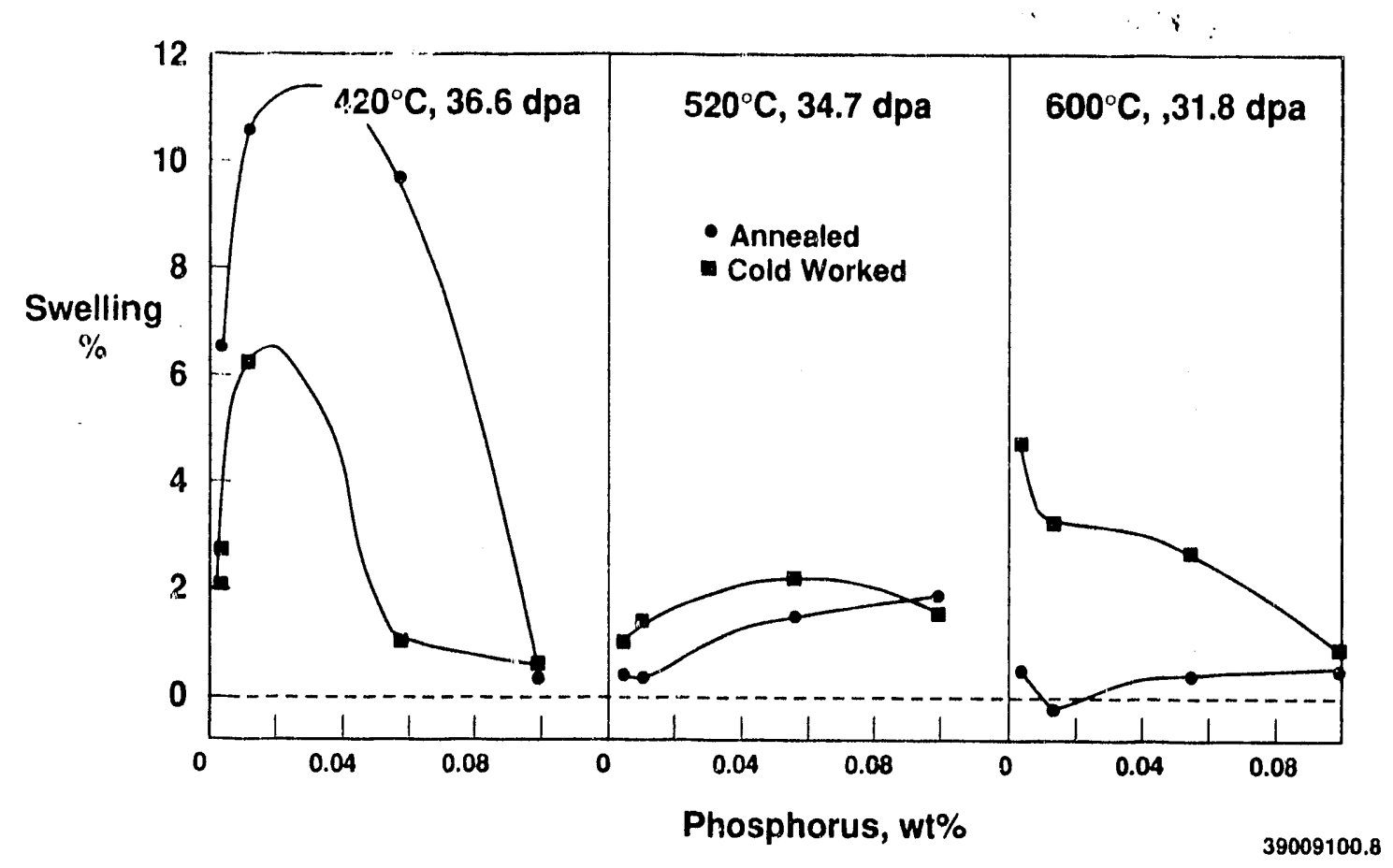

FIGURE 3. Swelling of Phosphorus-Modified Fe-15Cr-25Ni Alloys Observed in FFTF 
associated with phosphorus. Cold working reduces swelling at $420^{\circ} \mathrm{C}$, in agreement with the general observation of cold work's influence. The swelling falls quickly at higher temperatures in the annealed low phosphorus alloy, as was also observed in EBR-II. The curves for annealed materials at 520 and $600^{\circ} \mathrm{C}$ also exhibit the same dependence on phosphorus content as those observed in EBR-II.

There were several unusual features observed in these data, however. First, the cold worked condition swelled more than the annealed condition at 520 and $600^{\circ} \mathrm{C}$. Second, and possibly even more important, the reversal in swelling behavior with cold work was observed even in the lowest phosphorus alloy E33. Third, in the cold worked condition alloy E33 swelled more at $600^{\circ} \mathrm{C}$ and $31.8 \mathrm{dpa}$ than at $520^{\circ} \mathrm{C}$ and $34.7 \mathrm{dpa}$, as illustrated in Figure 4. This behavior with temperature was unexpected and indicates that the interactions of cold work with both phosphorus and temperature are more complex than previously envisioned.

The density change data of alloy E104 from the EBR-II AA-XIV experiment are shown in Table 2. The decrease of swelling with cold work at $420^{\circ} \mathrm{C}$ is

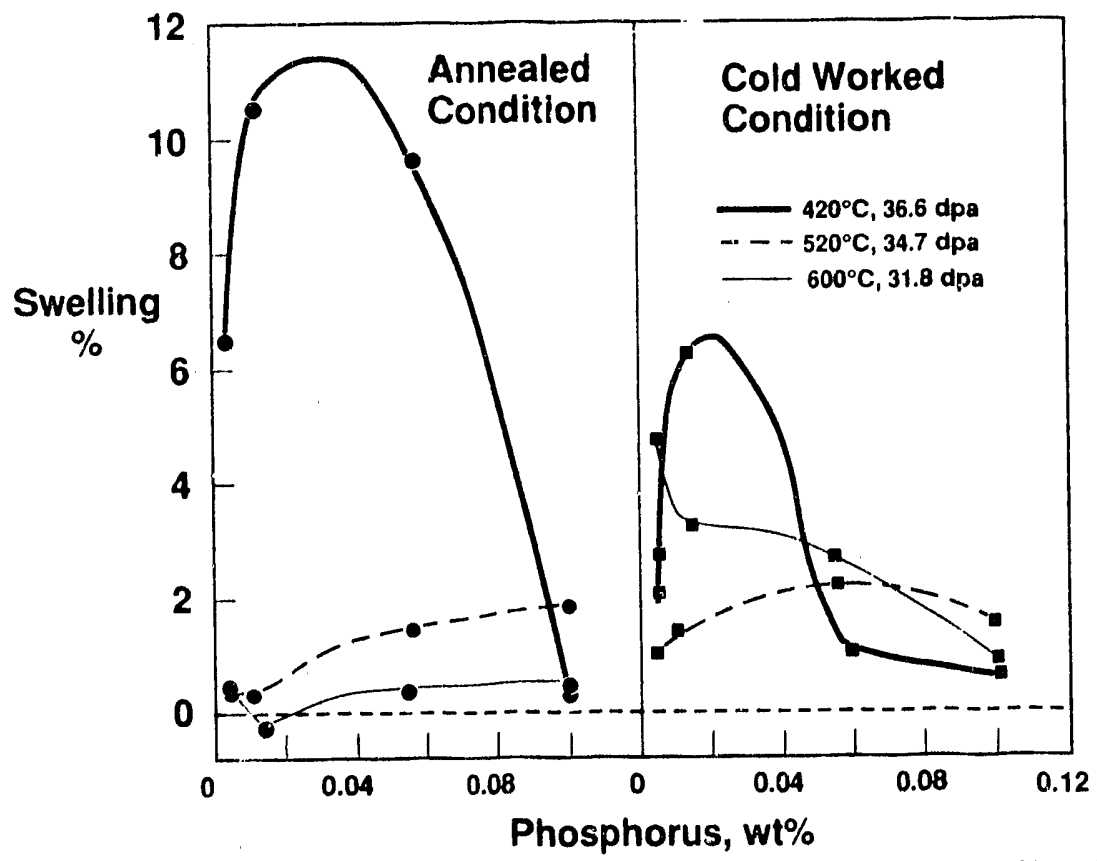

FIGURE 4. Data from Figure 3 Replotted to Emphasize the Effect of Temperature on Sweliing 
TABLE 2. Swelling (in \%) of Alloy El04 (Fe-15Cr-25Ni-0.055P) in the AA-XIV Experiment Irradiated in EBR-II to $14 \mathrm{dpa}$

\begin{tabular}{ccccc} 
Temperature, ${ }^{\circ} \mathrm{C}$ & Annealed & Cold Worked & & Cold Worked and Aged \\
\hline 420 & 1.79 & 0.28 & -0.36 \\
500 & -0.21 & -0.28 & $\mathrm{NA}(\mathrm{a})$ \\
600 & -0.03 & $\mathrm{NA}(\mathrm{a})$ & $\mathrm{NA}(\mathrm{a})$
\end{tabular}

(a) $\mathrm{NA}=$ not available.

consistent with the behavior observed in FFTF. The influence of increasing temperature at this low dose level does not yield the increase in swelling observed in FFTF, however.

\section{DISCUSSION}

The effects of cold working on complex alloys have been studied in many investigations, but only a few studies have explored the effects of cold working on single $\mathrm{Fe}-\mathrm{Cr}-\mathrm{Ni}$ ternary alloys. In one recent study conducted at very high helium/dpa ratios in ORR, Fe-25Ni-15Cr suffered a reduction in swelling from 1.04 to $0.29 \%$ upon $30 \%$ cold working and irradiation at $500^{\circ} \mathrm{C}$ to $13.6 \mathrm{dpa} .{ }^{(6)}$ Swelling at other irradiation temperatures in this experiment was too low to observe the influence of cold work. Similar behavior was observed in $\mathrm{Fe}-35 \mathrm{Ni}-15 \mathrm{Cr}$ at $500^{\circ} \mathrm{C}$, falling from 0.55 to $-0.11 \%$ with cold work.

The ${ }^{59} \mathrm{Ni}$-doping experiment at $495^{\circ} \mathrm{C}$ and $14 \mathrm{dpa}$ showed a reduction in swelling with cold work in $\mathrm{Fe}-15 \mathrm{Cr}-25 \mathrm{Ni}$ in the undoped condition and essentially no difference in the doped condition, which experienced a higher helium/dpa ratio. ${ }^{(5)}$ At $600^{\circ} \mathrm{C}$ and $8.8 \mathrm{dpa}$ this experiment did not produce sufficient swelling in $\mathrm{Fe}-15 \mathrm{Cr}-25 \mathrm{Ni}$ to assess the impact of cold work. (4) However, there did appear to be a slight enhancement of swelling in both the cold worked and annealed undoped conditions with phosphorus addition at $600^{\circ} \mathrm{C}$, in agreement with the present study.

The previously published EBR-II studies from the AA-VII experiment $(1,7)$ all involved the irradiation of ternary $\mathrm{Fe}-\mathrm{Cr}-\mathrm{Ni}$ alloys in the annealed condition. In one experiment designated AA-XII, however, both the annealed and $30 \%$ cold worked conditions of alloy E20 (Fe-24.4Ni-14.9Cr with $\leq 0.005 \mathrm{P})$ were irradiated side-by-side in EBR-II at 425 and $540^{\circ} \mathrm{C}$ to 18.5 and $24.5 \mathrm{dpa}$, 
respectively. (8) The E20 alloy and the E33 alloy of the current study are quite similar alloys prepared by the same vendor at the same time.

Note in Table 3 that the E20 alloy in EBR-II behaved the same as the E33 alloy in FFTF, showing a reduction in swelling with cold work at $425^{\circ} \mathrm{C}$ and an increase in swe 11 ing at $540^{\circ} \mathrm{C}$. Figure 5 compares the behavi $r$ of E2O in this and the earlier experiment. Note aiso that there is some variability in the response of the cold worked alloy. Such variability is frequently observed in cold worked alloys.

Table 3 also shows some previously unpublished results of another irradiation of the $E 20$ alloy in the AA-XIV experiment. At 14 dpa cold working decreases swelling at 425 and $500^{\circ} \mathrm{C}$ but increases it at $600^{\circ} \mathrm{C}$, once again demonstrating the reversal in the influence of cold work at higher temperatures.

TABLE 3. Swelling Observed in A110y E20 (Fe-24.4Ni-14.9Cr) in the $A A-X I$ and $A A-X I V$ Experiments in EBR-II

\begin{tabular}{|c|c|c|c|c|}
\hline \multicolumn{2}{|c|}{$\begin{array}{l}\text { Temperature, } \\
{ }^{\circ} \mathrm{C} \text {, and } \\
\text { Experiment } \\
\end{array}$} & \multirow{2}{*}{$\begin{array}{l}\text { Displacement } \\
\text { Level, dpa } \\
\begin{array}{c}18.5 \\
18.5\end{array}\end{array}$} & \multirow{2}{*}{$\begin{array}{l}\begin{array}{c}\text { Alloy } \\
\text { Condition }\end{array} \\
\text { annealed } \\
30 \% \mathrm{CW}\end{array}$} & \multirow{2}{*}{$\begin{array}{c}\begin{array}{c}\text { Swe } 11 \text { ing, } \\
\%\end{array} \\
\begin{array}{r}12.8^{(a)} \\
3.8^{(a)}\end{array}\end{array}$} \\
\hline $\begin{array}{l}425 \\
425\end{array}$ & $\begin{array}{l}A A-X I \\
A A-X I\end{array}$ & & & \\
\hline $\begin{array}{l}540 \\
540\end{array}$ & $\begin{array}{l}A A-X I \\
A A-X I\end{array}$ & $\begin{array}{l}24.5 \\
24.5\end{array}$ & $\begin{array}{l}\text { annealed } \\
30 \% \mathrm{CW}\end{array}$ & $\begin{array}{l}1.14(\mathrm{a}) \\
4.81 \text { (b) } \\
3.61 \text { (b) }\end{array}$ \\
\hline $\begin{array}{l}425 \\
425\end{array}$ & $\begin{array}{l}A A-X I V \\
A A-X I V\end{array}$ & $\begin{array}{l}14.0 \\
14.0\end{array}$ & $\begin{array}{l}\text { annealed } \\
30 \% \mathrm{CW}\end{array}$ & $\begin{array}{l}9.69(\mathrm{c}) \\
2.85(\mathrm{c})\end{array}$ \\
\hline $\begin{array}{l}500 \\
500\end{array}$ & $\begin{array}{l}A A-X I V \\
A A-X I V\end{array}$ & $\begin{array}{l}14.0 \\
14.0\end{array}$ & $\begin{array}{l}\text { annealed } \\
30 \% \mathrm{CW}\end{array}$ & $\begin{array}{r}1.80(\mathrm{c}) \\
-0.01(\mathrm{c})\end{array}$ \\
\hline $\begin{array}{l}600 \\
600\end{array}$ & $\begin{array}{l}A A-X I V \\
A A_{1}-X I V\end{array}$ & $\begin{array}{l}14.0 \\
14.0\end{array}$ & $\begin{array}{l}\text { annealed } \\
30 \% \mathrm{CW}\end{array}$ & $\begin{array}{l}0.35(c) \\
2.56(c)\end{array}$ \\
\hline
\end{tabular}
(a) Average swelling of four identical specimens exhibiting very small differences in density.
(b) Separate measurements on two nominally identical specimens.
(c) Measurement on one specimen onity. 
The action of cold work in enhancing swelling at higher tempeiatures may be similar to that observed recently in pure nickel, ${ }^{(9)}$ as shown in Figure 6. Microscopy studies now in progress show that the effect of cold work on the swelling of nickel at 500 and $600^{\circ} \mathrm{C}$ is to make it easier to establish (and maintain at higher temperatures) a saturation density of dislocations early in the irradiation, a condition which promotes early void nucleation. Swelling tends to saturate in pure nickel later in the irradiation because the dislocation density drops sharply once void swelling begins. Swelling of cold worked materials at high exposure therefore exhibits very little dependence on temperature.

Another comparison of the influence of cold work is shown in Table 4, which indicates that in FFTF Fe-7.5Cr-35Ni xhibited the expected behavior at 420 and $520^{\circ} \mathrm{C}$ but that large increases in swelling were observed at $600^{\circ} \mathrm{C}$. The variability of swelling when enhanced by cold work is agair: highlighted by the fact that swelling was increased relative to that of the annealed condition at $600^{\circ} \mathrm{C}$ at both 35 and $60 \mathrm{dpa}$, but was less at $60 \mathrm{dpa}$. It is not felt that swelling actually decreased on the average between 35 and $60 \mathrm{dpa}$;

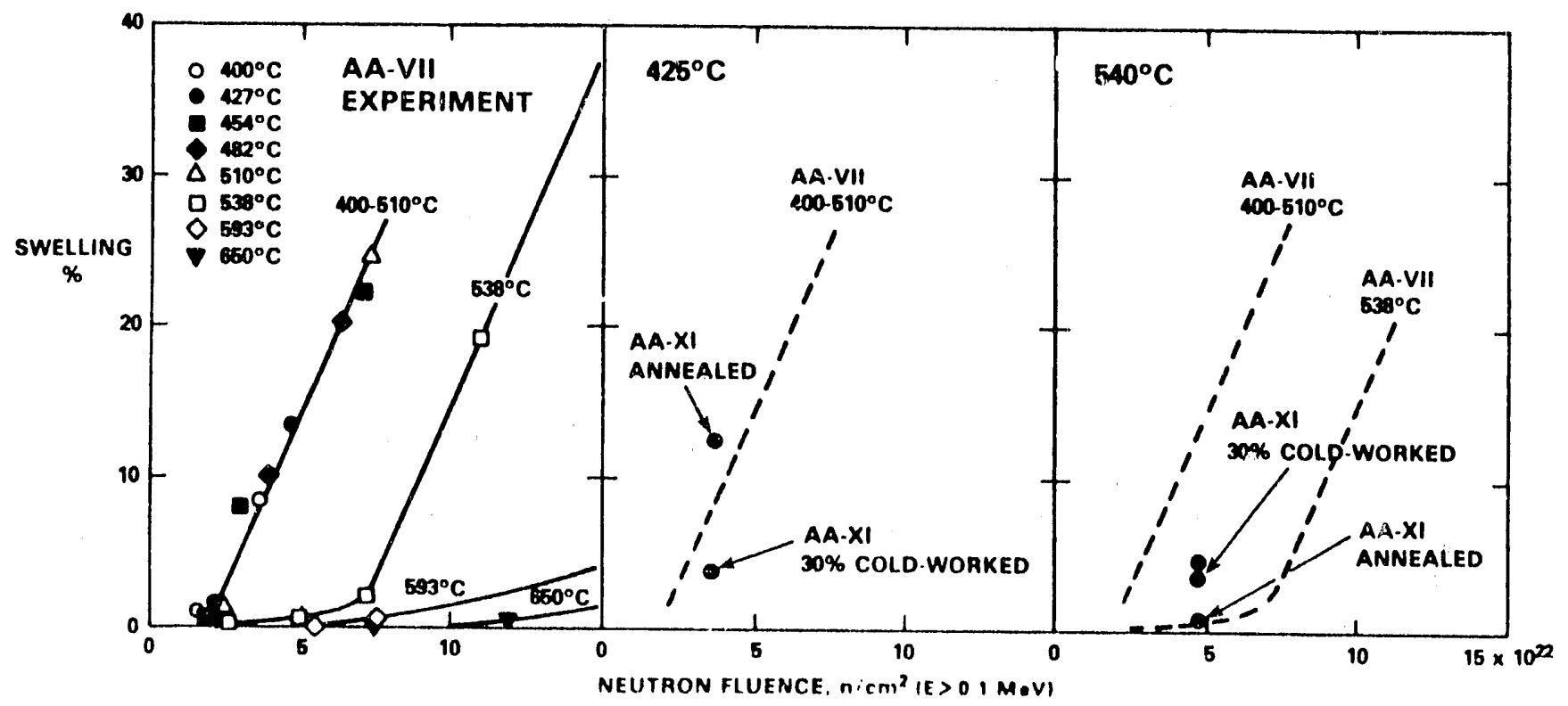

FIGURE 5. Swelling of Alloy E20 (Fe-24.4Ni-14.9Cr) in Two Separate EBR-II Experiments. Note in the two right hand figures that the influence of cold work reverses between 425 and $540^{\circ} \mathrm{C}$ in the AA-XI experiment. (8) 


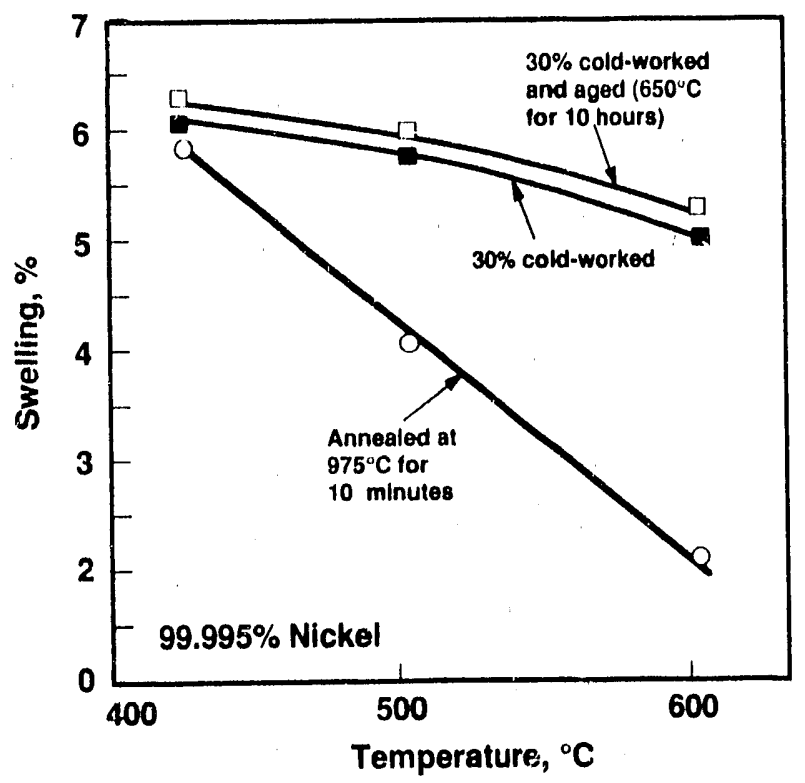

FIGURE 6. Swell ing of $99.99 \%$ Nickel Irradiated to $14 \mathrm{dpa}$ in the EBR-II AA-XIV Experiment. (9) The cold worked and cold worked and aged conditions do not exhibit the strong temperature dependence seen in the annealed steel.

rather, it is believed that the enhancement process is very sensitive to uncontrolled variables in the experiment, often varying between noilinally identical specimens irradiated in the same specimen packet.

The $\mathrm{Fe}-15 \mathrm{Cr}-25 \mathrm{Ni}$ alloy has been used as a standard material in a variety of irradiation studies conducted in the U.S. fusion and breeder reactor programs. One study not mentioned previously involved the use of this alloy in a correlation experiment between charged paricle and neutron irradiations. 10,11 In that study the softness of this material was highlighted, indicating the ease with which dislocations were introduced during specimen preparation and also the difficulty of maintaining them near specimen surfaces. Therefore, there may be some merit to the comparison between the behavior of nickel and $\mathrm{Fe}-15 \mathrm{Cr}-25 \mathrm{Ni}$ with respect to the influence of cold work at higher irradiation temperatures. Since phosphorus has been shown in type 316 stainless steel to assist in maintaining during irradiation the dislocation densities induced by cold work, (12) this may account for the strong increase in swelling at relatively high phosphorus levels observed ir Figures 3 and 4 , especially at higher temperatures where dislocations are more mobile. 
TABLE 4. Swelling Observed in Alloy E37 (Fe-7.5Cr-35Ni) in FFTF(a)

\begin{tabular}{|c|c|c|c|}
\hline $\begin{array}{c}\text { Temperature, } \\
{ }^{\circ} \mathrm{C} \\
\end{array}$ & $\begin{array}{l}\text { Displacement } \\
\text { Level, dpa }\end{array}$ & $\begin{array}{c}\text { Alloy } \\
\text { Condition }\end{array}$ & $\begin{array}{c}\text { Swelling, } \\
\%\end{array}$ \\
\hline $\begin{array}{l}420 \\
420\end{array}$ & $\begin{array}{l}9 \\
9\end{array}$ & $\begin{array}{l}\text { annealed } \\
30 \% \mathrm{CW}\end{array}$ & $\begin{array}{l}-0.16 \\
-0.26\end{array}$ \\
\hline $\begin{array}{l}420 \\
420\end{array}$ & $\begin{array}{l}46.5 \\
46.5\end{array}$ & $\begin{array}{l}\text { annealed } \\
30 \% \mathrm{CW}\end{array}$ & $\begin{array}{r}0.09 \\
-0.09\end{array}$ \\
\hline $\begin{array}{l}420 \\
420\end{array}$ & $\begin{array}{l}70 \\
70\end{array}$ & $\begin{array}{l}\text { annealed } \\
30 \% \mathrm{CW}\end{array}$ & $\begin{array}{l}0.09 \\
0.09\end{array}$ \\
\hline $\begin{array}{l}520 \\
520\end{array}$ & $\begin{array}{l}14 \\
14\end{array}$ & $\begin{array}{l}\text { annealed } \\
30 \% \mathrm{CW}\end{array}$ & $\begin{array}{l}0.16 \\
0.00\end{array}$ \\
\hline $\begin{array}{l}520 \\
520\end{array}$ & $\begin{array}{l}49.6 \\
49.6\end{array}$ & $\begin{array}{l}\text { annealed } \\
30 \% \mathrm{CW}\end{array}$ & $\begin{array}{r}0.30 \\
-0.36\end{array}$ \\
\hline $\begin{array}{l}520 \\
520\end{array}$ & $\begin{array}{l}75 \\
75\end{array}$ & $\begin{array}{l}\text { annealed } \\
30 \% \mathrm{CW}\end{array}$ & $\begin{array}{r}0.02 \\
-0.14\end{array}$ \\
\hline $\begin{array}{l}600 \\
600\end{array}$ & $\begin{array}{l}14 \\
14\end{array}$ & $\begin{array}{l}\text { annealed } \\
30 \% \mathrm{CW}\end{array}$ & ${ }_{N M}^{-0}(b)$ \\
\hline $\begin{array}{l}600 \\
600\end{array}$ & $\begin{array}{l}35 \\
35\end{array}$ & $\begin{array}{l}\text { annealed } \\
30 \% \mathrm{CW}\end{array}$ & $\begin{array}{l}0.20 \\
2.50\end{array}$ \\
\hline $\begin{array}{l}600 \\
600\end{array}$ & $\begin{array}{l}60 \\
60\end{array}$ & $\begin{array}{l}\text { annealed } \\
30 \% \mathrm{CW}\end{array}$ & $\begin{array}{l}0.12 \\
1.78\end{array}$ \\
\hline
\end{tabular}

(a) Measurements on one specimen each.

(b) $\mathrm{NM}=$ not measured.

Another series of ion irradiation studies by Lee and Mansur also highlighted the action of phosphorus to maintain dislocation densities. $(13,14)$ In their first study it was shown that two alloys ( $\mathrm{Fe}-13.7 \mathrm{Cr}-15 \mathrm{Ni}$ both with and without 0.05 wt\% phosphorus) both swelled at comparable levels when irradiated in the annealed condition to $\sim 90 \mathrm{dpa}$ at $675^{\circ} \mathrm{C}$ with nickel ions. (13) This is in agreement with the neutron studies, since the phosphorus-related peak in swelling was found to exist between these two phosphorus levels. Three other phosphorus-modified alloys with silicon, titanium and carbon additions were each found to exhibit less swelling in the annealed condition when subjected to a variety of irradiation sequences, some of which involved helium coinjection. The compositions of these alloys are listed in Table 5. 
TABLE 5. Ion-Irradiated Alloys Studied by Lee and Mansur $(13,14)$

\begin{tabular}{|c|c|}
\hline Alloy & Composition \\
\hline B10 & $\mathrm{Fe}-13.64 \mathrm{Cr}-15.15 \mathrm{Ni}-0.050 \mathrm{P}$ \\
\hline B11 & $\mathrm{Fe}-13.63 \mathrm{C} 4-15.20 \mathrm{Ni}-0.049 \mathrm{P}-0.18 \mathrm{Ti}-0.041 \mathrm{C}$ \\
\hline B12 & $\mathrm{Fe}-13.58 \mathrm{Cr}-15.15 \mathrm{Ni}-0.049 \mathrm{P}-0.17 \mathrm{Ti}-0.044 \mathrm{C}-0.83 \mathrm{Si}$ \\
\hline
\end{tabular}

In the second of these studies, ${ }^{14}$ the latter three alloys were irradiated at $675^{\circ} \mathrm{C}$ in the cold worked condition, but with higher levels of helium coinjection. Figure 7 compares the swelling of these alloys in the annealed and cold worked conditions, each data set taken from separate publications. $(13,14)$ Although it is not possible to make a comparison involving onlly a single variable due to the variations in helium injection schedules, Lee arid Mansur motheir expectation that both cold working and higher cavity densities induced by helium injection should depress swelling. Note in Figure 7 that if the differences in helium are ignored the opposite result is obtain; the cold worked condition of each alloy swells more than the annealed condition. This appears to confirm the conclusion of the current study concerning the interactive roles of cold work and phosphorus on void swelling.

\section{CONCLUSIONS}

Phosphorus additions can either increase or decrease void swelling of $\mathrm{Fe}-\mathrm{Cr}-\mathrm{Ni}$ alloys, depending on irradiation temperature, phosphorus level and the cold work level of the alloy. The role of cold work is not always to suppress swelling, however, particularly at relatively higher irradiation temperatures where swelling actually increases upon cold working. The dividing point where cold working reverses its role on swelling appears to lie between 520 and $540^{\circ} \mathrm{C}$ for displacement rates typical of fast reactor irradiation.

\section{FUTURE WORK}

This effort will continue, focusing on microscopy examination on specimens irradiated in either FFTF or EBR-II. 


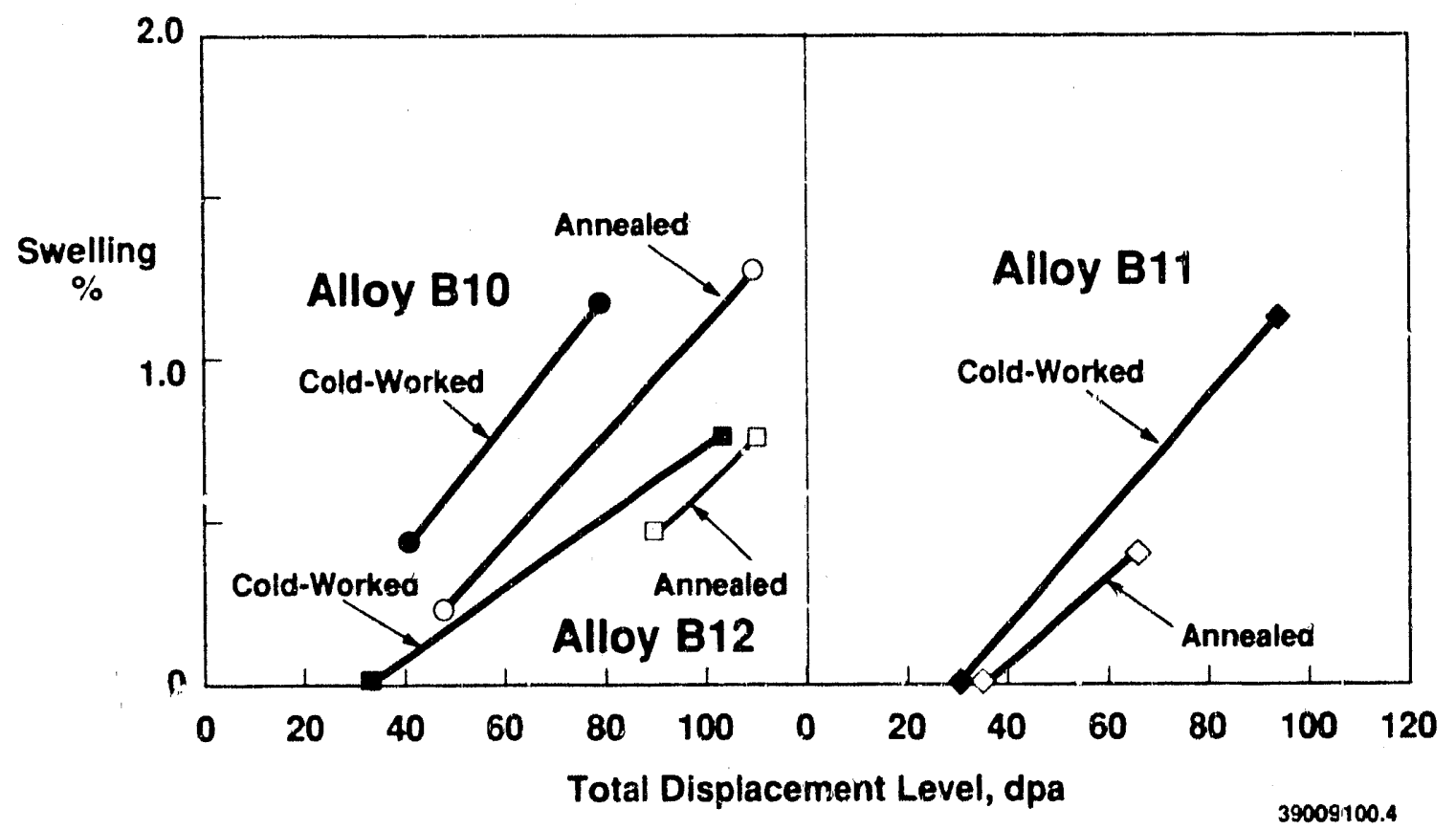

EIGUPE 7. Comparison of Ion-Induced Skelling of Varinus Phosphorus-Modified Alloys Irradiated at $675^{\circ} \mathrm{C}$,

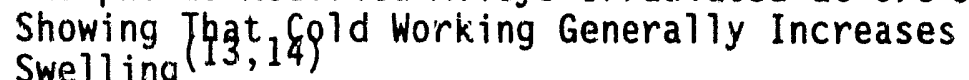

\section{REFERENCES}

1. F. A. Garner and A. S. Kumar, ASTM-STP 995 (1987) 289.

2. T. Muroga, F. A. Garner and J. M. McCarthy, J. Nilcl. Mater., 168 (1989) 109.

3. F. A. Garner, M. L. Hamilton, R. L. Simons and M. K. Maxon, J. Núcl. Mater. 176 (1990) in press, also DDE/ER-0313/8 (1990) 108.

4. H. Kawanishi, F. A. Garner and J. F. Stubbins, J. Nucl. Mater., 176 (1990) in press.

5. J. F. Stubbins, J. F. Nevling, F. A. Garner and R. L. Simons, ASTMSTP 1046 (1989) 147.

6. M. L. Hamilton, A. Okada and F. A. Garner, J. Nucl. Mater., 176 (1990) ir press.

7. F. A. Garner and H. R. Brager, ASTM STP 870 (1985) 187.

8. F. A. Garner and H. R. Brager, DOE/ER-0046/19 (1984) 62.

9. F. A. Garner, DOE/ER-0313/8 (1990) 125. 
10. F. A. Garner, J. Nuc1. Mater., 117 (1983) 177.

11. F. A. Garner and seventeen coauthors, in Proceedings of a Workshop on Correlation of Neutron and Charged Particle Damage, CONF-760673, Oak Ridge, TN, June 1976, 177.

12. M. Itoh, S. Onose and S. Yuhara, ASTM STP 955 (1987) 114.

13. E. H. Lee and L. K. Mansur, J. Nucl. Mater., 141-143 (1986) 695.

14. E. H. Lee and L. K. Mansur, Phi1. Mag. A, 61 (1990) 733. 

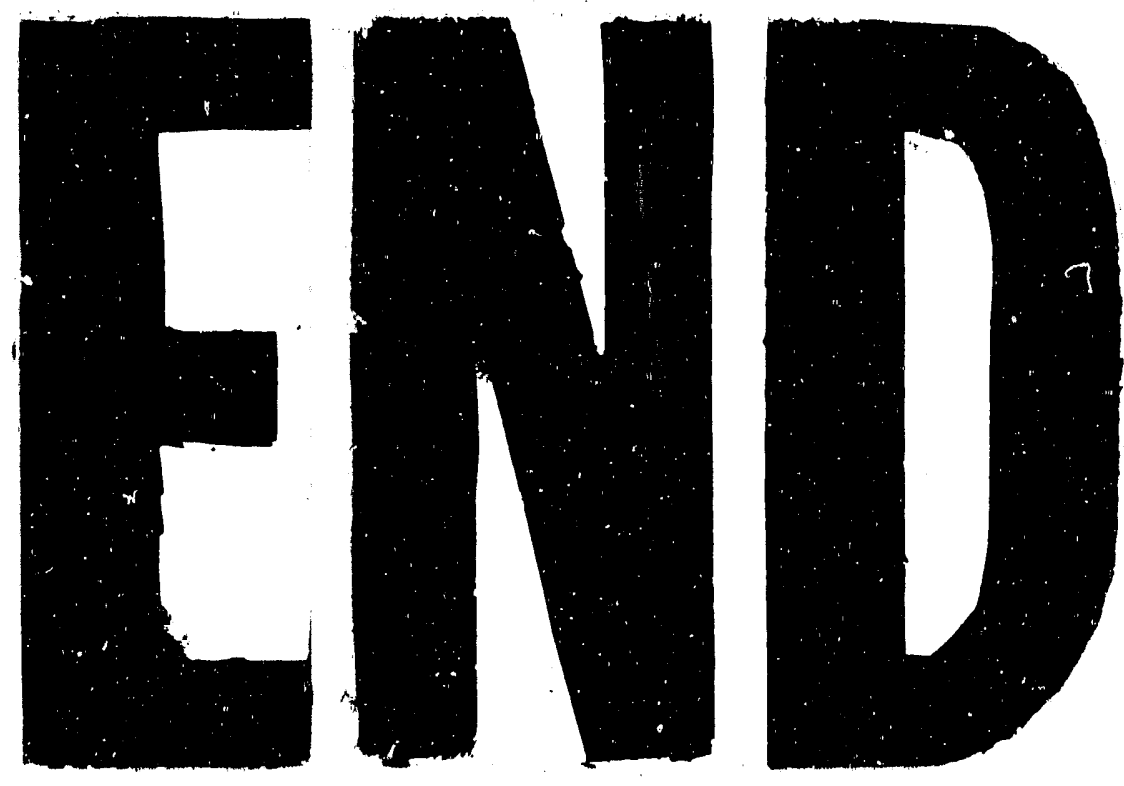

(4)
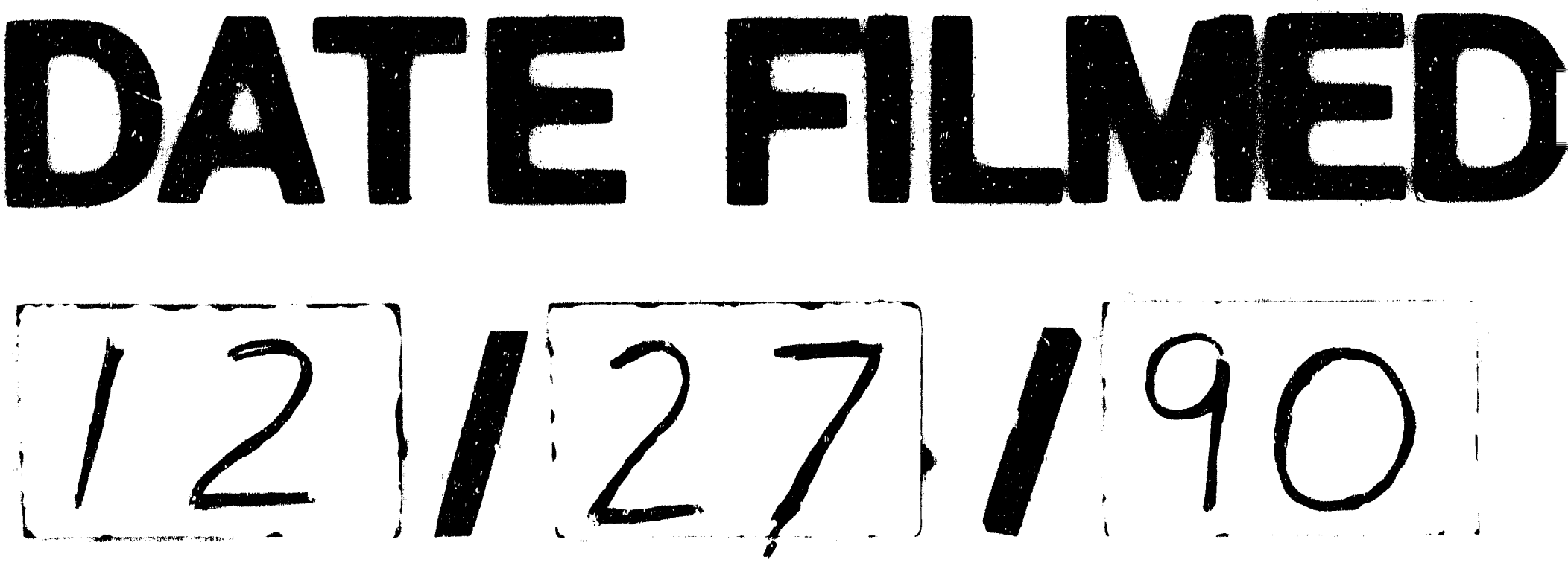
